\title{
Influence of Tax Administration on Investment Processes
}

\author{
Alexandrov G.A.* \\ Tver State Technical University \\ Tver, Russia \\ e-mail: g-alexandrov@rambler.ru
}

\author{
Vyakina I.V. \\ Tver State Technical University \\ Tver, Russia \\ e-mail: vyakina@yahoo.com
}

\author{
Skvortsova G.G. \\ Tver State Technical University \\ Tver, Russia \\ e-mail: gala-skvortsova@yandex.ru
}

\begin{abstract}
Despite the high losses of the state budget due to tax benefits, the introduced tax investment incentives did not lead to the increase in business investment. A review of the scientific literature indicates conflicting results justifying the effectiveness of tax investment incentives in different countries. Consequently, an objective assessment of the effectiveness of changes in tax legislation, analysis and generalization of the practice of tax benefits are becoming extremely relevant in this situation. The article aims at summarizing world experience and the Russian practice of tax incentives for investment activities and assessing the impact of tax administration on investment processes. Based on the comparative analysis of the tax incentives use, the authors conclude that the tax incentives are completely ineffective in attracting investments in countries with poor investment climate and low quality of public administration. In such conditions, the introduction of tax benefits seems to be of little value, since a correlation-significant relationship between tax benefits and the level of investment has not detected. Low tax rates provide powerful investment incentives only in well-governed countries. Empirical studies of tax incentives for attracting investment today go from developing bold hypotheses about the impact of taxation on investments to implementing their results in investment policy both at the national and sub-national levels around the world.
\end{abstract}

Keywords - investments, tax investment incentives, tax administration

\section{INTRODUCTION}

The state as the main subject of investment process administration can regulate, control and stimulate them. Taxes are one of the most important economic mechanisms for influencing business processes. Tax policy directly affects the development of the national economy.

High tax rates or suboptimal tax accounting can lead to very unfavorable consequences for business or cause bankruptcy of enterprises. On the other hand, the competent use of existing legislative tax benefits can ensure not only the safety of the received financial savings, but also the ability to finance expansion of activities, new investments by saving on tax payments or returning previously paid tax payments from the budget.
Tax administration is one of the economic methods of managing and achieving a balance of national interests with the commercial interests of entrepreneurs and organizations, regardless of the type of economic activity, ownership, and legal form. It regulates foreign economic activity, including attracting direct investment, forms net profit. Through taxes, the state can contribute to the development of high-tech industries and priority sectors of the national economy. Nevertheless, the questions of the impact of tax incentives and investment incentives on the influx of investments in the country, regions, and specific spheres of industry are still debatable.

\section{LITERATURE REVIEW}

Tax relations between the state and business are still, perhaps, the main subject of discussion about the ways and methods of reforming the economy, and criticize both in our country and abroad.

The existence of a connection between tax incentives and raising capital justified back in the 1960s. The neoclassical theory of investment, presented in 1963 [1, p. 247] argued that enterprises will continue to accumulate capital as long as the cost of this is less than the benefits. Due to the diminishing return on additional capital, investment will carry out while the current return on invested capital will exceed the present value of investment costs. Since before taxes, the rate of return on capital regards as the cost of capital, lower tax rates reduce the cost of capital and increase investment in fixed assets.

Thus, according to [2], in conditions of increased concentration of business, more developed territories attract more foreign direct investment. While in areas with the worst investment climate, it is advisable to use measures to reduce the tax burden.

There is an opinion shared by Portuguese scientists [3] that the policy of providing tax benefits is more effective than a simple tax cut. At the same time, other scientists adhere to the opposite point of view. Critics of using tax incentives to attract investment claim that tax incentives distort investment decisions and can contribute to misallocation of resources. In addition, tax breaks lead to loss of budget revenues. 
Some researchers [4] believe that the available empirical evidence on the cost-effectiveness of such incentives is very inconclusive, especially in developing countries. The authors conclude that the use of tax incentives should limit due to the presence of imperfect competitive market structures, while preference should give only to those tax incentives that provide a faster return on investment costs.

In paper [5], cautious attitude expressed regarding the use of tax incentives for attracting investments, and arguments for and against tax incentives and selection criteria for determining the effectiveness of various tax incentives depending on the specific conditions of the country presented.

Scientists [6] researching the use of tax incentives in developing countries prove that infrastructure, human capital and institutions have a large impact on attracting investment compared to tax incentives. Similar conclusions were formulated in an article by South African authors [7] who believe that despite the important role in attracting investments played by tax incentives, they are effective for attracting any significant investments only in combination with non-tax measures, especially if availability of developed infrastructure.

On the other hand, many researchers [8] argue that developing countries, as a rule, face with problems of tax administration, institutional barriers, and high share of the shadow sector and massive loss of budget revenues due to tax evasion. The increase in the tax burden under such conditions and the loss of the possibility of tax evasion may push officially registered companies to move to the informal sector. Hence, tax incentives use as a counterweight to underdeveloped infrastructure and high transaction costs, which increase the cost of doing business. Thus, lowering tax rates helps to cover the associated losses of investors.

On the empirical data, the authors of [9] study the effect of tax rates on income from labor and capital, and conclude that tax incentives are most stimulating during periods of recovery and have less impact during periods of recession.

In [10], the impact of the uncertainty in the economic and tax policies on company investments estimates. Based on empirical data, the authors concluded that the uncertainty in economic policy leads to instability at the micro level and the lack of investment plans for enterprises. When enterprises doubt the costs due to possible changes in the rules of doing business and taxes, they prefer to abandon the planning of investment projects.

It should note that in most studies, it is concluded that although tax incentives may be important in attracting foreign and domestic investment, they are more effective in combination with other non-tax factors. Among them are called the general economic conditions for doing business, infrastructure, legal factors, the quality of management and developed institutions that increase the investment attractiveness of the territory.

Economic feasibility requires the most efficient use of productive resources, at the same time, the globalization of the economy and international economic and trade integration have led production to move to places where manufacturing activities have comparative advantages over other territories.
The application of tax incentives implies that they increase profit after tax, so the investor prefer a territory with lower tax liability in case other conditions are similar. Thus, conditions for tax competition between territories for lowering tax rates create.

\section{METHODS}

The approaches to the study of the tax incentives problem in attracting mobile capital differ in the scope and methodology. Most foreign studies in this area based on the use of econometric analysis and mathematical modeling. This study aims at a critical analysis of the theory and practice of applying tax incentives to attract investment and the systematization of knowledge and experience in their application recently. In the course of the work, methods of a systematic, logical, and comparative analysis of scientific literature have used, descriptive statistics have analyzed taking into account the assessment of hierarchical and correlation dependencies between empirical data. The conclusions, analytical data and materials obtained during the preparation of the article have summarized and structured in terms of logic and in accordance with the results obtained on the topic of the study.

\section{RESULTS AND DISCUSSION}

The tax policy in the Russian Federation is mainly aimed at the implementation of the fiscal function, which is confirmed by the excess of the growth rate of tax revenues over the growth rates of the main macroeconomic indicators, that is, the growth of tax revenues significantly outstrips the growth of GDP, the study notes [11]. However, in addition to performing the fiscal function, tax policy should provide incentives for the development of individual regions and activities.

Despite the high budget expenditures of the state associated with tax benefits, a significant increase in investment in connection with the introduction of tax investment incentives has not yet observed. Moreover, the application of certain tax benefits leads to significant budget losses.

In terms of creating a comfortable tax environment for the implementation of new investment projects in Russia, many tax mechanisms are currently to stimulate investment. They are accelerated depreciation, amortization premium, it is possible to get a "deferral" of direct taxes - corporate income tax and corporate property tax, special tax regimes and tax holidays for small businesses applies.

The analysis of the application of tax investment benefits for income tax, value added tax and property tax of organizations in different constituent entities of the Russian Federation, performed by [12, p. 55], indicates, that investors do not actively use the tax preferences and benefits available in the tax legislation of the Russian Federation due to their inexpediency and inefficiency. Therefore, changes should made to the current tax legislation related to the accounting for depreciation, corporate income tax, property tax, with a reduction in VAT and a revision of the distribution of taxes transferred to the budgets of the constituent entities of the 
Russian Federation and their municipalities in favor of expanding the tax powers of the territories.

However, since 2018, the regions have received the right to introduce an investment tax benefit to stimulate investment. The legislator provided the opportunity to reduce the corporate income tax to the regional budget to 90 percent of the amount of expenses for the acquisition, technical re-equipment, etc. fixed assets of 3-7 depreciation groups. The tax reduces, but tax base does not. The organization takes into account expenses for the acquisition of fixed assets in the income tax expense through depreciation during the useful life of the object, which, for example, for the seventh depreciation group is 15-20 years. When applying the investment tax deduction for the remaining 10 percent of expenses, it is possible to reduce profit tax to the federal budget to zero.

According to the Ministry of Economic Development, the investment tax deduction has not yet worked. Based on the results for 2018 and the first half of 2019, this benefit was formally accepted in 14 regions, but only two companies in the Khanty-Mansiysk District applied it in reality with the amount of tax deductions to the regional budget of 3.0 million rubles for the specified period.

The right to reduce the tax base by the amount of investments existed in the framework of the previously existing Law of the Russian Federation of December 27, 1991, No. 2116-1 "On tax on profits of enterprises and organizations", but was abolished with the introduction of the new Tax Code. In various versions of the draft chapter 25 of the Tax Code of the Russian Federation, a phased cancellation of this benefit planned, but as a result of the benefit completely canceled. The main reason for the abolition of this benefit was budget losses. [13, p. 174-175]. There was an opinion that the elimination of this benefit should have been compensated by the introduction of an accelerated depreciation mechanism. However, accelerated depreciation and investment deduction differ in essence: accelerated depreciation is the accumulation of funds for the future, and investment deduction is the compensation of costs after spending.

In addition, in order to apply the investment deduction for income tax, it is necessary to have a profit and, as a result, a calculated income tax payable to the budget, thus, a lossmaking organization is not be able to claim an investment deduction.

Meanwhile, according to statistics, the share of unprofitable enterprises over the past 5 years remains unchanged at about 30 percent. The pre-tax profit for such an industry as mining according to the financial statements for 2017 amounted to 2,508,466,799 thousand rubles. Most of the profits came from organizations engaged in oil and gas production, while peat extraction organizations accounted for only 47,558 thousand rubles. In agriculture, profit amounted to $244,994,695$ thousand rubles. In construction, according to the financial statements, there was a loss of $22,265,851$ thousand rubles. ${ }^{1}$

\footnotetext{
${ }^{1}$ Federal State Statistics Service: URL:https://www.fedstat.ru/indicator/58259
}

In our opinion, it is advisable to consider expanding the application of tax holidays for organizations of individual industries. Today, the tax holiday regime is available only to individual entrepreneurs applying the simplified taxation system and individual entrepreneurs applying the patent taxation system.

The complicated administrative procedure for applying an investment tax credit makes difficult its use in practice. B.Kh. Aliyev claims that stimulating investment activity with the tax instruments in the form of an investment tax credit remained declarative, and does not affect the investment activity of economic entities [14]

The application of an investment tax credit for regional taxes complicates by the presence of gaps in tax legislation. Subparagraph 7 of paragraph 1 of Article 63 of the Tax Code of the Russian Federation gives regions of the Russian Federation the right to determine the body authorized to make a decision on the provision of an investment tax credit, but the procedure for making such a decision rigidly fixes in the Tax Code of the Russian Federation. Article 67 of the Tax Code states that an investment tax credit is granted by an organization's application and formalized in agreement. At the same time, the documents giving the basis for the provision of an investment tax credit by the Tax Code do not clearly defined. In this case, the question remains open of the need to coordinate the decisions of regional authorities with the tax authorities, as well as the verification and examination of documents by the Tax Code of the Russian Federation. In our opinion, the absence of a clear procedure for deciding on the provision of an investment tax credit is the cause of isolated cases of using this tax preference by taxpayers. In addition, the lack of a clear decision-making procedure gives the decision maker unreasonably broad rights and can lead to corruption, that is, become a source of investment risk.

The study [15, p. 625] summarizes the opinions of enterprise managers, which allows identifying the main problems that reduce the effect of the introduction of tax benefits in Russian practice:

- instability of legislation;

- difficulty of challenging the claims of the tax inspectorate and documenting benefits;

- ambiguous interpretation of certain legislative norms;

- lack of precedents for the practical application of certain tax benefits in the practice of accounting and tax accounting;

- high rates of actual inflation, due to which the released funds are not enough for investment activities:

- lack of experience in applying legal norms and a flexible system of differentiated benefits and rates for decades.

The volatility and uncertainty of Russian tax policy, according to entrepreneurs, is a serious problem that impedes investment activity. 
Tax uncertainty at the domestic level, according to experts, is associated with institutional problems in tax policy and fuzzy tax rules. This statement has confirmed by empirical studies at the micro level of other foreign authors [16, p. 42]

The same trends are observed in the case of political uncertainty. Under the conditions of different levels of government in the Russian Federation, the results of studies by Chinese authors, describing the volatility of corporate investments towards the frequent change of decision-making officials in government bodies, seem to be interesting. The mentioned study conducts on the data about the changes of government officials in 277 Chinese cities. Frequent changes of persons who make the decisions in the field of economic policy depend, leads to the fact that firms significantly reduce investment in fixed assets, especially when the new officials did not belong to the local authorities before, but were appointed by the higher-level government. The decrease in investment during a period of political uncertainty is more characteristic of state enterprises, capital-intensive companies and key enterprises at the local level [17, p. 188].

Many researchers, in particular [18, p. 125], consider the problems of tax administration, institutional barriers, a high share of the shadow sector and massive loss of budget revenues due to tax evasion characteristic of developing countries. Hence, tax incentives are used as a counterweight to underdeveloped infrastructure and high transaction costs, which increase the cost of doing business. The influence of tax policy on the security of economic systems also investigates by domestic scientists studying the mechanism of attracting investments, for example $[19,20]$.

Some scientists and practitioners [21, 22] are attempting to assess the effectiveness of tax incentives, but significant methodological problems also arise in this direction. The draft Decree of the Government of the Russian Federation "On approval of the Methodology for assessing the effectiveness of tax benefits (tax expenses) of the constituent entities of the Russian Federation and municipal entities" (prepared by the Ministry of Finance of Russia on March 16, 2018) requires improvement.

\section{CONCLUSION}

Researches in different countries and regions show that there is no single conclusion about the effectiveness of tax incentives, and the results are vary depending on the countries and analysis methods used in the study. World experience in tax incentives application indicates their effectiveness in the case of non-tax determinants of doing business, which are more important for potential investors. Among them the quality of public administration, infrastructure, institutional environment and the level of the financial market development put in the first place.

Reforming the current Russian system of tax incentives for investment activities involves monitoring, analysis and evaluation of existing tax incentives in order to identify and eliminate ineffective, inapplicable (applied in isolated cases) or outdated benefits; reduction in the total number of benefits, a clearer formulation of the procedure for their provision; development and introduction of new, most effective ways to encourage investment in fixed assets.

\section{Acknowledgment}

The reported study was funded by RFBR, project number 19-010-00032.

\section{References}

[1] D.W. Jorgenson, "Capital Theory and Investment Behavior", Amer. Econ. Rev., vol. 53, no. 2, pp. 247-259, 1963. Retrieved from: https://www.jstor.org/stable/1823868

[2] S. Van Parys, S. James, "The effectiveness of tax incentives in attracting investment: panel data evidence from the CFA Franc zone", Int. Tax and Public Finance, vol. 17, no. 4, pp. 400-429, 2010. Retrieved from: https://doi.org/10.1007/s10797-010-9140-1

[3] D. Barbosa, V.M. Carvalho, P.J. Pereira, "Public stimulus for private investment: An extended real options model", Econ. Modell., vol. 52, Part B, pp. 742-748, 2016. Retrieved from: https://doi.org/10.1016/j.econmod.2015.10.013

[4] H.H. Zee, J.G. Stotsky, E. Ley, "Tax Incentives for Business Investment: A Primer for Policy Makers in Developing Countries", World Development, vol. 30, no. 9, pp. 1497-1516, 2002. Retrieved from: https://doi.org/10.1016/S0305-750X(02)00050-5

[5] A. Klemm, "Causes, benefits, and risks of business tax incentives", Int. Tax and Public Finance, vol. 17, no. 3, pp 315-336, 2010. Retrieved from: https://doi.org/10.1007/s10797-010-9135-y

[6] T. Kinda, "The Quest for Non-Resource-Based FDI; Do Taxes Matter?", IMF Working Papers 14/15, 2014. International Monetary Fund. Retrieved from: https://ideas.repec.org/p/imf/imfwpa/14-15.html

[7] S. Munongo, O.A. Akanbi, Z. Robinson, "Do tax incentives matter for investment? A literature review", Busin. and Econ. Horizons, vol.13, no. 2, pp. 152-168, 2017. Retrieved from: http://dx.doi.org/10.15208/ beh.2017.12

[8] J.J. Lopez, "A quantitative theory of tax evasion", J. of Macroecon., vol. 53, pp. 107-126, 2017. Retrieved from: https://doi.org/10.1016/ j.jmacro. 2017.06.005

[9] E. Sims, J. Wolff, "The state-dependent effects of tax shocks", Europ. Econ. Rev., vol. 107, pp. 57-85, 2018. Retrieved from: https://doi.org/10.1016/j.euroecorev.2018.05.002

[10] W. Kang, K. Lee, R.A. Ratti, "Economic policy uncertainty and firmlevel investment”, J. of Macroecon., vol. 39, Part A, pp. 42-53, 2014. Retrieved from: https://doi.org/10.1016/j.jmacro.2013.10.006

[11] N.I. Malis, "Medium-term tax policy: optimization of benefits and investment promotion”, Res. Financial Instit. Financial magazine, vol. 3, pp. 89-95, 2014. Retrieved from: http://www.finjournalnifi.ru/images/FILES/Journal/Archive/2014/3/fm_2014_3.pdf /

[12] O.N. Savina, "Current instruments to stimulate investment processes in modern economic conditions and proposals for their improvement", Financial analyt.: probl. and solutions, vol. 6, pp. 43-57, 2015. Retrieved from: https://www.fin-izdat.ru/journal/fa/detail.php?ID=64767

[13] G.A. Alexandrov, Attractiveness of the investment climate and investment risks: methodology, diagnostic tools and evaluation methods. 2020, pp. 174-175. DOI: 10.18334/9785912923050

[14] B.Kh. Aliyev, R.M. Magomedova, Z.A. Kazimagomedova, Enhancing the incentive role of tax incentives in the mechanism of the formation of new institutions of territorial development, vol. 27, no. 402, pp. 12-23, 2015

[15] I.V. Vyakina, "Tax Investment Incentives: Worldwide Experience and Russian Practice", Modernizat. innovation. Res., no. 9-4, pp, 618-631, 2018. Retrieved from: https://doi.org/10.18184/2079-4665.2018.9.4.618631

[16] W. Kang, K. Lee, R.A. Ratti, "Economic policy uncertainty and firm-level investment", Journal of Macroeconomics, vol. 39, Part A, pp. 42-53, 2014. Retrieved from: https://doi.org/10.1016/j.jmacro. 2013.10.006 
[17] H. An, Y. Chen, Luo, T. Zhang, "Political uncertainty and corporate investment: Evid D.ence from China", Journal of Corporate Finance, vol. 36, pp. 174-189, 2016. Retrieved from: https://doi.org/10.1016/j. jcorpfin.2015.11.003

[18] J.J. Lopez, “A quantitative theory of tax evasion”, Journal of Macroeconomics, vol. 53, pp. 107-126, 2017. Retrieved from: https://doi.org/10.1016/j. jmacro.2017.06.005

[19] V.Y. Padalkin, A.I. Khorev, A.M. Prygunkov, L.I. Churikov, "The impact of tax planning on the level of economic security of the company", Proceedings of the Voronezh State University of Engineering Technologies, vol. 81, no. 2, pp. 383-386, 2019. Retrieved from: https://doi.org/10.20914/2310-1202-2019-2-383-386
[20] A.N. Desyatirikov, Y.B. Nechaev, E.N. Desyatirikova, E.A. Lyutova, "The mechanism of attracting investment in the regional economy on the example of the Voronezh region", Proceedings of the Voronezh State University of Engineering Technologies, vol. 80, no. 4, pp. 378-383, 2018. Retrieved from: https://doi.org/10.20914/2310-1202-2018-4-378383

[21] A.N. Prostenko, V.L. Anichie, A.I. Khudobin, @ Tax incentives as a tool to stimulate investment activity in the region@ Bulletin of the Kursk State Agricultural Academy, vol. 2, pp. 162-166, 2019. Retrieved from: https://elibrary.ru/item.asp?id=37209193

[22] L.V. Shevyrkov, "Methodology for assessing tax benefits at the local level", University Herald, vol. 6, pp. 117-122, 2018. Retrieved from: https://doi.org/10.26425/1816-4277-2018-6-117-122 